\begin{tabular}{|c|c|c|}
\hline$W_{\text {INESEG }}$ & $\begin{array}{l}\text { INTERNATIONAL } \\
\text { ENGINEERING, } \\
\text { SCIENCE AND } \\
\text { EDUCATION } \\
\text { GROUP }\end{array}$ & $\begin{array}{l}\text { Middle East Journal of Science } \\
\text { (2017) 3(2): } 69-82 \\
\text { Published online December 25, } 2017 \quad \text { (http://dergipark.gov.tr/mejs) } \\
\text { doi: } 10.23884 / \text { mejs.2017.3.2.01 } \\
\text { ISSN: } 2536-5312 \\
\text { Received: September 02,2017 } \quad \text { Accepted: October 15.2017 }\end{array}$ \\
\hline
\end{tabular}

\title{
ANALYSIS OF CLIMATIC TRENDS IN EVAPORATION FOR ÇANAKKALE (TURKEY)
}

\author{
Semih KALE ${ }^{* 1}$ \\ ${ }^{* 1}$ Çanakkale Onsekiz Mart University, Faculty of Marine Sciences and Technology, Department of \\ Fishing and Fish Processing Technology, Terzioğlu Campus, 17020 Çanakkale, Turkey \\ *semihkale@comu.edu.tr
}

\begin{abstract}
In this study, temporal changes and trends in the series of annual, seasonal, and monthly evaporation of Çanakkale station of Turkish State Meteorological Service were analyzed. Time series of evaporation data set has been organized as climatological seasons that spring (March, April, May), summer (June, July, August), autumn (September, October, November), and winter (December, January, February). Non-parametric tests and BoxJenkins method were used to determine climatic trends. Pettitt change-point analysis was applied to determine the change point of evaporation. Trend analysis results showed that a statistically significant increasing trend occurred in evaporation. Mean annual evaporation is estimated to increase $1.4498 \mathrm{~mm}$ per year and it is anticipated to reach $215.3356 \mathrm{~mm}$ in 2022. Furthermore, mean seasonal evaporation are estimated to increase 1.2251 $\mathrm{mm}, 1.6485 \mathrm{~mm}$, and $0.4117 \mathrm{~mm}$ per year for spring, summer, and autumn, respectively. Therefore, Çanakkale is thought to be affected by global warming and climate change and this effect will continue. Evaporation should be continuously measured and monitoring program should be established to allow sustainable use and management of water resources. Global or regional climate change scenarios and projections must be considered in order to moderate the possible effects of climate change and global warming on Çanakkale.
\end{abstract}

Key words: Climate change, Evaporation, Trend analysis, Çanakkale 


\section{Introduction}

Evaporation is an important climatic factor affecting life of animal and plant. Changes in evaporation have big effect on management and planning of water resources, agricultural production, and irrigation control [1]. Climate change resulting from global warming has a significant impact on evaporation. Therefore, availability of water resources are affected by these changes [2]. Although changing climatic conditions, determination of evaporation trends will contribute to revealing the possible effects of climate change on evaporation.

Several authors analyzed climatic trends in evaporation that lead to different results for many regions around the world. Increasing trends in evaporation were reported in Israel [3], Brazil [4], eastern Asia including Tibetan Plateau, China and Japan [5], western Africa [6] and Iran [7]. On the other hand, decreasing trends were also reported in the USA [8], the USA and former Soviet Union [9], Italy [10], Australia [11], Japan [12], China [13-14], Thailand [15-16], Canada [2], and India [1, 17]. In Turkey, although many researchers [18-33] have investigated climatic changes in temperature and precipitation, the same interest has not been shown for evaporation. However, studies conducted on temporal trends in evaporation have been reported to be slightly different results in different regions. [34] found a declining trend in the evaporation in the south east of Turkey. Nevertheless, [35] reported that evaporation in 5 of the 9 stations evaluated in the study conducted in the west of Turkey showed a tendency to decrease while it showed an increasing tendency at 4 stations. In other studies carried out in the west of Turkey, increasing trend in evaporation have been reported [36-41].

Çanakkale plays a key role and makes a huge contribution for national agriculture production. Any major change in water structures can have serious consequences for hydrological processes. Therefore, studies on the monitoring of evaporation levels in Çanakkale are important for the sustainable use and management of water resources and agricultural activities. In this context, this study has been carried out to investigate the temporal changes of evaporation in Çanakkale by annual, seasonal and monthly analyses and to determine climatic trends of evaporation.

\section{Material and Method}

\subsection{Study Area and Climatic Data}

Climatic data used in this study were obtained from Çanakkale meteorological observation station (Figure 1) of Turkish State Meteorological Service (TSMS). These climatic data consists of measured evaporation data between 1971 and 2011. Time series were arranged as climatic seasons that spring (March, April, May), summer (June, July, August), autumn (September, October, November) and winter (December, January, February). 


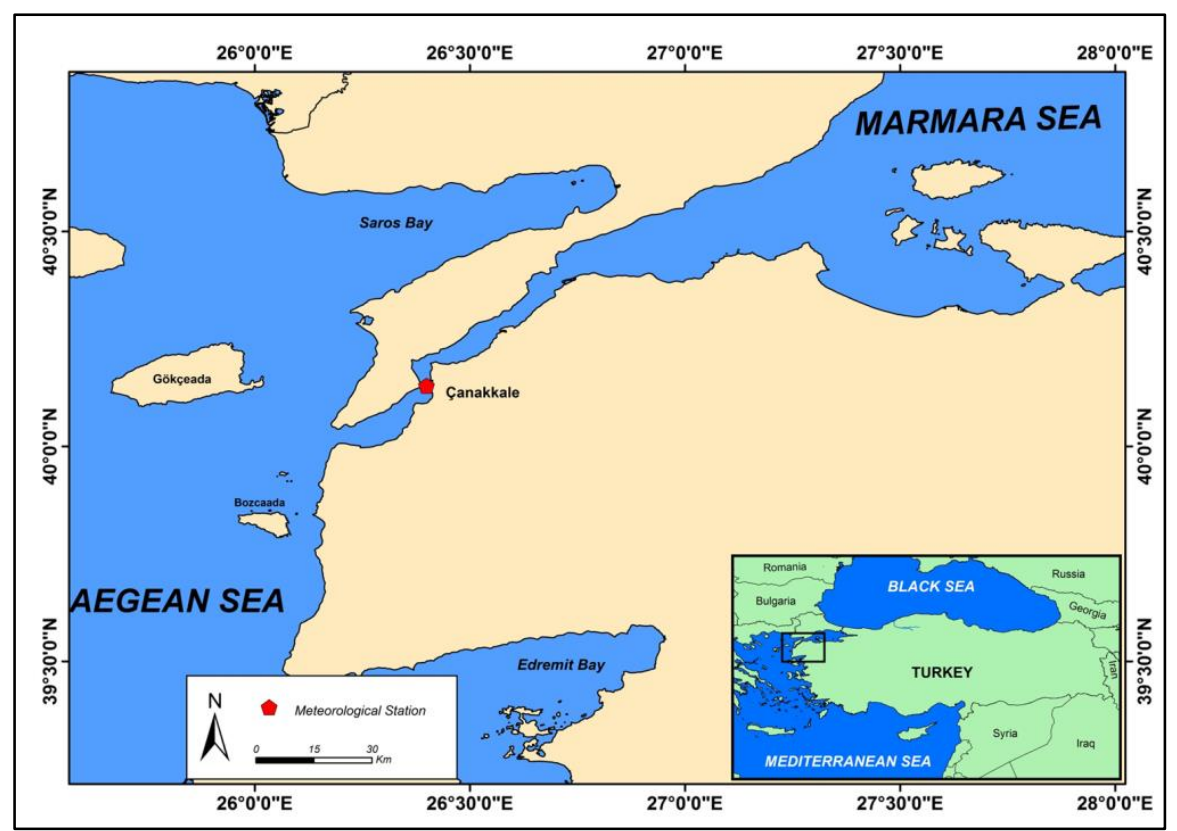

Figure 1. The location of the meteorological observation station

Çanakkale is located in the west of Turkey. It is surrounded by Aegean Sea, Marmara Sea and Çanakkale Strait. It has a transition climate type and summer is hot and dry while winter is cold and rainy. Mean monthly temperatures show that July is the warmest month while January is the coldest month with the long term averages of $6.4^{\circ} \mathrm{C}$ and $25^{\circ} \mathrm{C}$ [42].

\subsection{Change Point Analysis}

A non-parametric approach developed by Pettitt [43] was used to determine the change point of evaporation data. This approach determines a significant change in the time series which is time of change is exactly unknown. This non-parametric test is described below:

$$
\begin{aligned}
& K_{T}=\max \left|U_{t, T}\right| \text { and for } t=2, \ldots \ldots, T, \\
& U_{t, T}=\sum_{i=1}^{t} \sum_{j=t+1}^{T} \operatorname{sgn}\left(x_{i}-x_{j}\right)
\end{aligned}
$$

$U_{t, T}$ confirms that whether both samples are in the same population or not. The null hypothesis of Pettitt test is that there is no change point in the dataset. Test statistic $\left(K_{T}\right)$ and related probability $(p)$ are used for significance calculating. The probability of significance for the test statistic is estimated with

$$
\mathrm{p} \cong 2 \exp \left(\frac{-6 \mathrm{~K}_{\mathrm{T}}^{2}}{\mathrm{~T}^{3}+\mathrm{T}^{2}}\right)
$$

Pettitt change point analysis was executed with the usage of "trend" package [45] in R statistical software [44]. 


\subsection{Trend Analysis}

Trend analysis is the widely used method for detecting changes in the time series of climatic data [46]. Box-Jenkins method was applied for determining trends in mean annual, seasonal, and monthly evaporation. This method is based on linear, discontinuous and stochastic processes, and used for forecast and analysis of a time series. Autoregressive (AR), moving average (MA), and Autoregressivemoving average (ARMA) models are used for stationary processes while autoregressive integrated moving average (ARIMA) is used for non- stationary processes. These models aimed to decide that which model fits best and includes least parameter [47]. ARIMA model used in this study is explained as follow:

$$
X_{t}=c+\Phi_{1} X_{t-1}+\cdots+\Phi_{p} X_{t-p}+\theta_{1} e_{t-1}+\theta_{q} e_{t-q}+e_{t}
$$

$X_{t}$ is a variable that will be explain at $t$ time, $\Phi$ is the coefficient of per $p$ parameter, $\theta$ is the coefficient of per $q$ parameter, $c$ is the constant, and $e_{t}$ is error at $t$ time.

\subsection{Mann-Kendall Test}

Non-parametric Mann-Kendall test [48-49] is a commonly used test for determining trends in the time series. Average is affected by extreme values in the dataset. [36] pointed out that Mann-Kendall test is an effective test to determine the trends in the time series contain extreme values. Kendall's tau and Spearman's rho tests were applied to investigate possible trends in evaporation. These nonparametric tests provide more fitting and trustworthy results than parametric tests. Mann-Kendall test is explained below.

$$
\begin{aligned}
& S=\sum_{i=1}^{n-1} \sum_{k=i+1}^{n} \operatorname{sgn}\left(x_{k}-x_{i}\right) \\
& Z_{c}= \begin{cases}\frac{S-1}{\sqrt{\operatorname{var}(S)},}, & S>0 \\
\frac{S+1}{\sqrt{\operatorname{var}(S)},}, & S=0\end{cases}
\end{aligned}
$$

$Z_{c}$ is the test statistic, $H_{0}$ will be rejected if $\left|Z_{c}\right|>Z_{l-\alpha / 2}$ when $Z_{l-\alpha / 2}$ is standard normal variable and $\alpha$ is the degree of significance. Trend magnitude can be determined as follow:

$$
\beta=\operatorname{Median}\left(\frac{x_{i}-x_{j}}{i-j}\right), \forall_{j}<i
$$

where $1<j<i<n$. A negative value of $\beta$ indicates a decreasing trend while a positive value of $\beta$ indicates an increasing trend. 


\section{Results and Discussion}

Time series were identified and change points of evaporation were determined annually, seasonally and monthly. There are no records of evaporation measurements for winter period including December, January, February and March.

Pettitt's change point analysis results indicated that change point for mean annual evaporation was 1992 (Table 1). Trend analysis results pointed out that mean annual evaporation has increasing trend (Figure 2). This increase was found statistically significant ( $\mathrm{p}<0.01)$. Mean annual evaporation is forecasted to increase $1.4498 \mathrm{~mm} / \mathrm{yr}$ and to reach $215.3356 \mathrm{~mm}$ in 2022 (Table 2).

Table 1. Results of non-parametric statistic tests and change years of evaporation

\begin{tabular}{|c|c|c|c|c|c|}
\hline \multirow{2}{*}{$\begin{array}{c}\text { Mean } \\
\text { Evaporation } \\
(\mathbf{m m})\end{array}$} & \multirow{2}{*}{$\begin{array}{l}\text { Pettitt } \\
\text { Change } \\
\text { Points }\end{array}$} & \multicolumn{2}{|c|}{ Mann-Kendall } & \multicolumn{2}{|c|}{ Spearman } \\
\hline & & tau & $p$ & rho & $p$ \\
\hline Annual & 1992 & $0.524^{* *}$ & 0.000 & $0.693^{* *}$ & 0.000 \\
\hline Spring & 1992 & $0.490^{* *}$ & 0.000 & $0.683^{* *}$ & 0.000 \\
\hline$\Xi$ Summer & 1992 & $0.359^{* *}$ & 0.001 & $0.505^{* *}$ & 0.001 \\
\hline §ँ Autumn & 1984 & 0.206 & 0.058 & 0.292 & 0.064 \\
\hline Winter & $\mathrm{NA}^{\mathrm{a}}$ & $\mathrm{NA}^{\mathrm{a}}$ & $\mathrm{NA}^{\mathrm{a}}$ & $\mathrm{NA}^{\mathrm{a}}$ & $\mathrm{NA}^{\mathrm{a}}$ \\
\hline January & $\mathrm{NA}^{\mathrm{a}}$ & $\mathrm{NA}^{\mathrm{a}}$ & $\mathrm{NA}^{\mathrm{a}}$ & $\mathrm{NA}^{\mathrm{a}}$ & $\mathrm{NA}^{\mathrm{a}}$ \\
\hline February & $\mathrm{NA}^{\mathrm{a}}$ & $\mathrm{NA}^{\mathrm{a}}$ & $\mathrm{NA}^{\mathrm{a}}$ & $\mathrm{NA}^{\mathrm{a}}$ & $\mathrm{NA}^{\mathrm{a}}$ \\
\hline March & $\mathrm{NA}^{\mathrm{a}}$ & $\mathrm{NA}^{\mathrm{a}}$ & $\mathrm{NA}^{\mathrm{a}}$ & $\mathrm{NA}^{\mathrm{a}}$ & $\mathrm{NA}^{\mathrm{a}}$ \\
\hline April & 1996 & $0.238^{*}$ & 0.028 & $0.344^{*}$ & 0.028 \\
\hline May & 1993 & $0.315^{* *}$ & 0.004 & $0.519^{* *}$ & 0.001 \\
\hline June & 1992 & $0.272^{*}$ & 0.012 & $0.394^{*}$ & 0.011 \\
\hline$\sum$ July & 1992 & $0.379^{* *}$ & 0.000 & $0.530^{* *}$ & 0.000 \\
\hline August & 1995 & $0.315^{* *}$ & 0.004 & $0.441^{* *}$ & 0.004 \\
\hline September & 1995 & $0.244^{*}$ & 0.025 & $0.360^{*}$ & 0.021 \\
\hline October & 1992 & 0.158 & 0.147 & 0.202 & 0.204 \\
\hline November & 1984 & 0.020 & 0.889 & -0.008 & 0.971 \\
\hline December & $\mathrm{NA}^{\mathrm{a}}$ & $\mathrm{NA}^{\mathrm{a}}$ & $\mathrm{NA}^{\mathrm{a}}$ & $\mathrm{NA}^{\mathrm{a}}$ & $\mathrm{NA}^{\mathrm{a}}$ \\
\hline
\end{tabular}

${ }^{*}$ Correlation is found significant at 0.05 level.

** Correlation is found significant at 0.01 level.

${ }^{a} N A$ indicates that evaporation could not measure due to freezing of the water in evaporation pans. 


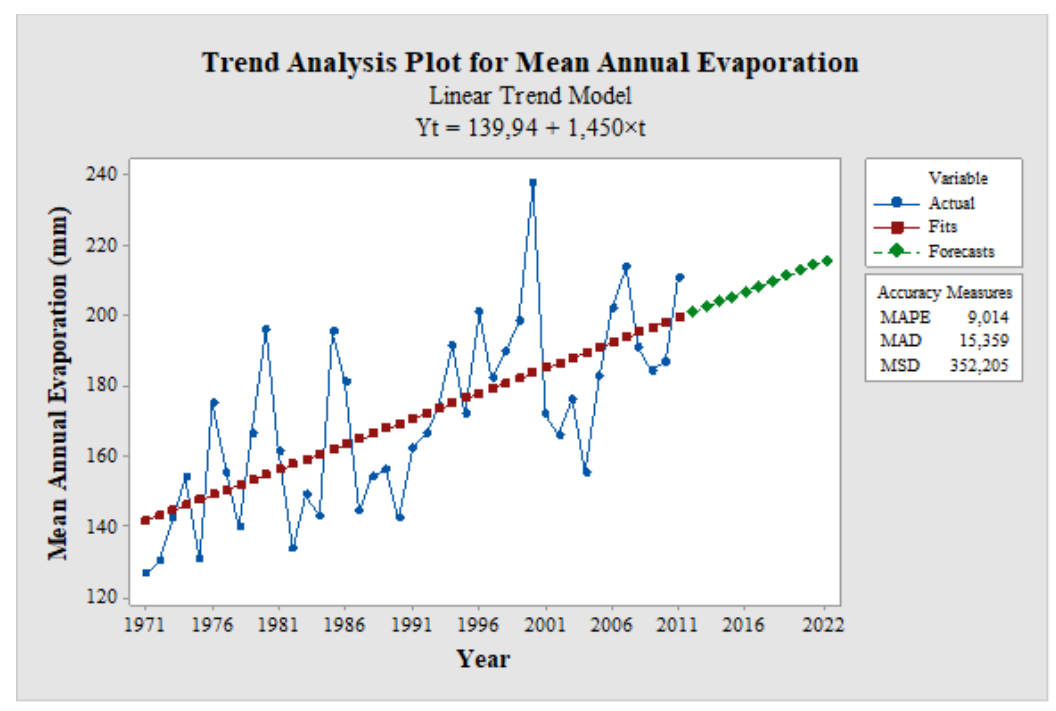

Figure 2. Trend analysis results of mean annual evaporation

Change points of mean seasonal evaporation for spring, summer, and autumn were determined as 1992, 1992, and 1984, respectively (Table 1). Results of trend analysis showed that evaporation tends to increase for all seasons (Figure 3). This trend was found statistically insignificant for autumn while significant $(\mathrm{p}<0.01)$ for spring and summer. Mean seasonal evaporation is predicted to increase 1.2251 $\mathrm{mm}, 1.6485 \mathrm{~mm}$, and $0.4117 \mathrm{~mm}$ per season and to reach $174.2956 \mathrm{~mm}, 295.7466 \mathrm{~mm}$, and 134.2265 $\mathrm{mm}$ in 2022 for spring, summer, and autumn, respectively (Table 2).

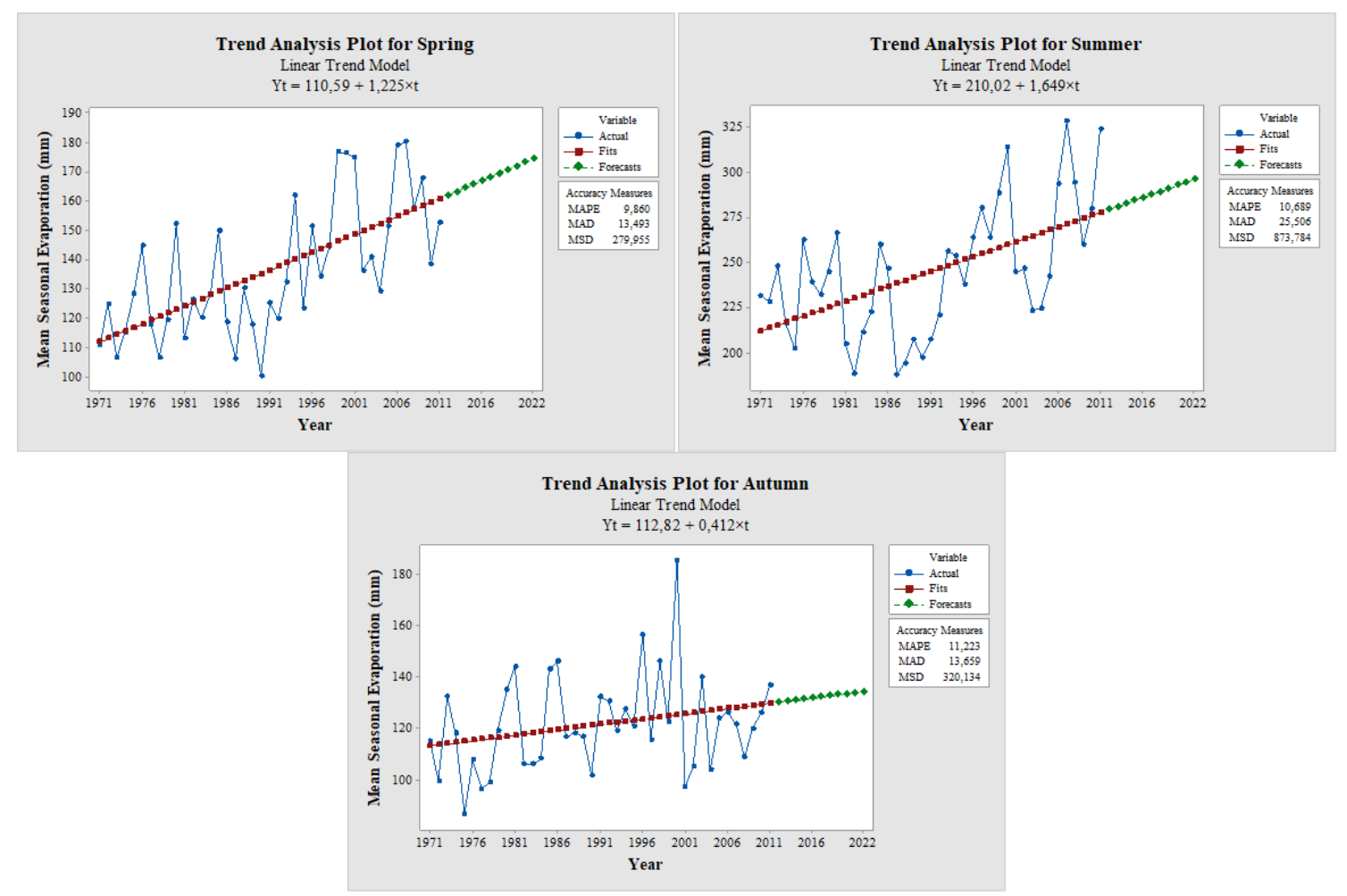

Figure 3. Trend analysis results for mean seasonal evaporation

Change points for mean monthly evaporation were given in Table 1. Unfortunately, change point analysis and trend analysis could not be carried out for January, February, March and December because 
of the evaporation values were not measured due to freezing of the water in evaporation pans. For the other months, trend analysis results pointed out that there were increasing trends for all months (Figure 4). These increasing trends were also found statistically significant for all months excepting October and November. Moreover, a significance level was determined at the 0.01 level for May, July, and August while at the 0.05 level for April, June, and September. Mean monthly evaporation is predicted to increase $0.6036 \mathrm{~mm} / \mathrm{yr}, 1.3912 \mathrm{~mm} / \mathrm{yr}, 1.3958 \mathrm{~mm} / \mathrm{yr}, 1.9744 \mathrm{~mm} / \mathrm{yr}, 1.5753 \mathrm{~mm} / \mathrm{yr}, 0.7964 \mathrm{~mm} / \mathrm{yr}$, $0.2804 \mathrm{~mm} / \mathrm{yr}$ and $0.0166 \mathrm{~mm} / \mathrm{yr}$ from April to November. Furthermore, it is expected that mean monthly evaporation will reach $128.5132 \mathrm{~mm}, 209.2809 \mathrm{~mm}, 260.7406 \mathrm{~mm}, 327.7129 \mathrm{~mm}, 298.7870$ $\mathrm{mm}, 195.5405 \mathrm{~mm}, 112.6295 \mathrm{~mm}$, and $61.9774 \mathrm{~mm}$ in 2022, respectively (Table 2).

Table 2. Forecasted values of evaporation for 2018-2022

\begin{tabular}{|c|c|c|c|c|c|c|}
\hline \multirow{2}{*}{\multicolumn{2}{|c|}{ Evaporation (mm) }} & \multicolumn{5}{|c|}{ Years } \\
\hline & & 2018 & 2019 & 2020 & 2021 & 2022 \\
\hline \multicolumn{2}{|c|}{ Mean Annual } & 209.5363 & 210.9861 & 212.4359 & 213.8858 & 215.3356 \\
\hline \multirow{4}{*}{ 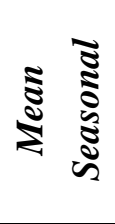 } & Spring & 169.3951 & 170.6202 & 171.8453 & 173.0704 & 174.2956 \\
\hline & Summer & 289.1526 & 290.8011 & 292.4496 & 294.0981 & 295.7466 \\
\hline & Autumn & 132.5799 & 132.9916 & 133.4032 & 133.8149 & 134.2265 \\
\hline & Winter & $\mathrm{NA}^{*}$ & $\mathrm{NA}^{*}$ & $\mathrm{NA}^{*}$ & $\mathrm{NA}^{*}$ & $\mathrm{NA}^{*}$ \\
\hline \multirow{12}{*}{ 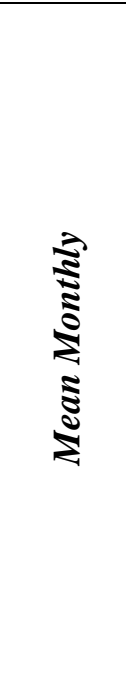 } & January & $\mathrm{NA}^{*}$ & $\mathrm{NA}^{*}$ & $\mathrm{NA}^{*}$ & $\mathrm{NA}^{*}$ & $\mathrm{NA}^{*}$ \\
\hline & February & $\mathrm{NA}^{*}$ & $\mathrm{NA}^{*}$ & $\mathrm{NA}^{*}$ & $\mathrm{NA}^{*}$ & $\mathrm{NA}^{*}$ \\
\hline & March & $\mathrm{NA}^{*}$ & $\mathrm{NA}^{*}$ & $\mathrm{NA}^{*}$ & $\mathrm{NA}^{*}$ & $\mathrm{NA}^{*}$ \\
\hline & April & 126.0989 & 126.7024 & 127.3060 & 127.9096 & 128.5132 \\
\hline & May & 203.7161 & 205.1073 & 206.4985 & 207.8897 & 209.2809 \\
\hline & June & 255.1574 & 256.5532 & 257.9490 & 259.3448 & 260.7406 \\
\hline & July & 319.8154 & 321.7898 & 323.7641 & 325.7385 & 327.7129 \\
\hline & August & 292.4856 & 294.0610 & 295.6363 & 297.2117 & 298.7870 \\
\hline & September & 192.3548 & 193.1512 & 193.9476 & 194.7441 & 195.5405 \\
\hline & October & 111.5079 & 111.7883 & 112.0687 & 112.3491 & 112.6295 \\
\hline & November & 61.9112 & 61.9277 & 61.9443 & 61.9609 & 61.9774 \\
\hline & December & $\mathrm{NA}^{*}$ & $\mathrm{NA}^{*}$ & $\mathrm{NA}^{*}$ & $\mathrm{NA}^{*}$ & $\mathrm{NA}^{*}$ \\
\hline
\end{tabular}

${ }^{*} N A$ indicates that evaporation could not measure due to freezing of the water in evaporation pans.

In this study, maximum evaporation value was recorded in July 2011 by $366.6 \mathrm{~mm}$ while minimum value was recorded in November 1975 by $41.6 \mathrm{~mm}$ (Table 3). The highest mean annual evaporation was calculated in 1971 while the lowest was measured in 2000. For seasonal evaporation values, the highest evaporation was observed in 2007, 2007, and 2000; and the lowest was observed in 1990, 1987, and 1975 for spring, summer, and autumn, respectively. On the other hand, maximum evaporation values for mean monthly evaporation were measured in 2006, 1999, 2000, 2011, 2007, 2000, 2000, 1998; and minimum values were measured in 1990, 1987, 1988, 1982, 1975, 1977, 1975, 1975 from April to November, respectively (Table 3). 

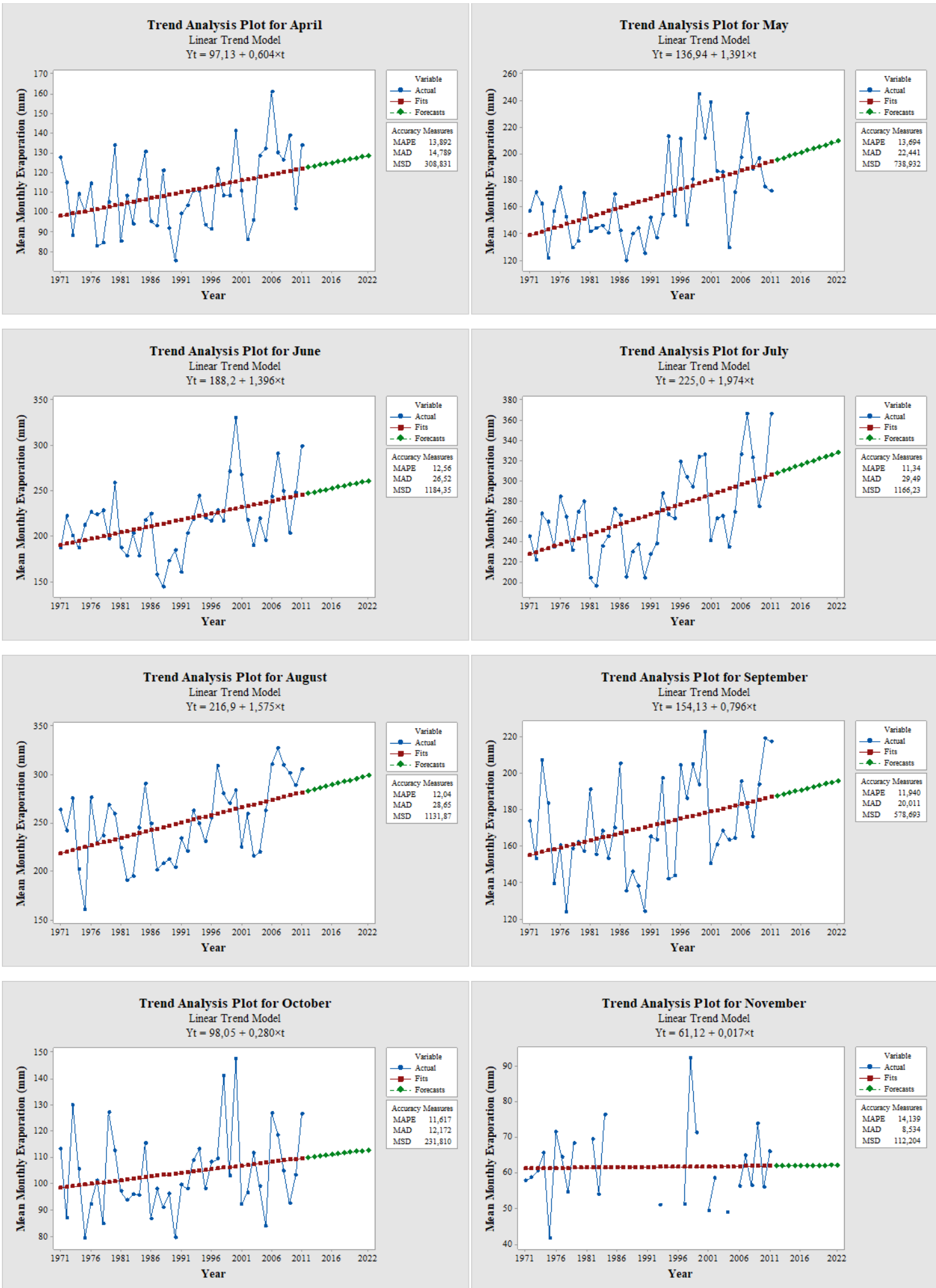

Figure 4. Trend analysis results for mean monthly evaporation

Table 3. Maximum and minimum values of mean evaporation for annual, seasonal and monthly

Period

Mean Evaporation (mm) 


\begin{tabular}{|c|c|c|c|}
\hline & Anпиаl & 126.33 & 237.53 \\
\hline \multirow{3}{*}{ 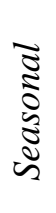 } & Spring & 100.30 & 180.10 \\
\hline & Summer & 187.67 & 328.07 \\
\hline & Autumn & 86.70 & 185.00 \\
\hline \multirow{8}{*}{ 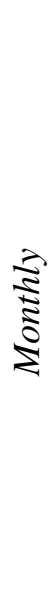 } & April & 75.40 & 161.20 \\
\hline & May & 119.60 & 245.00 \\
\hline & June & 144.20 & 330.70 \\
\hline & July & 195.50 & 366.60 \\
\hline & August & 159.80 & 327.10 \\
\hline & September & 123.70 & 222.60 \\
\hline & October & 79.20 & 147.40 \\
\hline & November & 41.60 & 92.10 \\
\hline
\end{tabular}

Evaporation measurements are requiring both more time and high-costly equipment [50]. Moreover, measurements could not be carried out due to the freezing of the water in evaporation pans when the air temperature is low. On the other hand, it is widely known that evaporation occurs during periods even the temperature is low. Evaporation occurs at high level in hot periods while at low level in cold periods.

A better understanding of future trends in evaporation due to climate change is of a great importance. This requires to revealing the structure of local or regional changes and the response given to the observed changes in a better way [51]. There are many studies worldwide that found both increasing and decreasing trend for evaporation. [8] reported a significant decreasing trend in the USA, Europe, Middle Asian and Siberian regions of the former Soviet Union for the period of 1945-1990. Decreasing trends were also reported in India [1, 17, 52], Canada [2], Italy [10], Japan [12], China [1314], Australia [11], and Thailand [15-16]. [53] pointed out that evaporation for New Zealand was decreasing $2 \mathrm{~mm}$ annually since 1970. [54] stated that evaporation was statistically significantly decreased with average $3.3 \mathrm{~mm} / \mathrm{yr}$ in Mexico for 1961-2010. On the other hand, statistically significant increasing trends were also reported in the south of Europe [55] and Middle East [56]. The largest change was reported by $97 \mathrm{~mm}$ increase for the western USA in a warm season during past 45 years [57]. Likewise, increasing trends were reported in Israel [3], Brazil [4], eastern Asia [5], western Africa [6], and Iran [7]. In Turkey, [34] reported a decreasing trend while [35] reported both decreasing and increasing trends in different regions. [38-41] reported increasing trend and forecasted to increase in the future projections. Similarly, in this study, evaporation is predicted to increase by annual, seasonal and monthly analyses.

Although there are contradictions in the results of studies on climatic trends of evaporation, there are different ideas to explain this paradox. Worldwide studies have shown that evaporation is affected by climatic factors such as wind speed [58-60] and air temperature [38-41, 61]. [57] reported that the decrease in evaporation is also related to the decrease in temperature and the increase in low cloud cover. 
Therewithal, [62] reported that increased evaporation may be associated with global warming. Therefore, it is known that evaporation will increase with the temperature increases. Similarly, the results of this study also show that the evaporation tends to increase with the effect of the increase in temperature due to global warming.

\section{Conclusion}

In conclusion, it has been determined that there is a statistically significant upward trend in mean annual, seasonal and monthly evaporation for Çanakkale. It is predicted that evaporation will increase in future projections. Therefore, Çanakkale is thought to be affected by global warming and climate change and this effect will continue. Monitoring the changes in the amount of evaporation contributes to the prediction of changes in the volumes of available water resources. Evaporation should be continuously measured and monitoring program should be established to allow sustainable use and management of water resources and to continue of agricultural activities in an efficient manner. Global or regional climate change scenarios and projections must be considered in order to moderate the possible effects of climate change and global warming on Çanakkale.

\section{Acknowledgement}

Author would like to thanks to Turkish State Meteorological Service and Fatih Mutlu for providing climatic data.

\section{References}

[1] Jhajharia, D., Shrivastava, S.K., Sarkar, D., Sarkar, S. (2009) Temporal characteristics of pan evaporation trends under the humid conditions of northeast India. Agricultural and Forest Meteorology, 149, 763-770.

[2] Burn, D.H., Hesch, N.M. (2007) Trends in evaporation for the Canadian Prairies. Journal of Hydrology, 36, 61-73.

[3] Cohen, S., Ianetz, A., Stanhill, G. (2002) Evaporative climate changes at Bet Dagan, Israel, 19641998. Agricultural and Forest Meteorology, 111 (2), 83-91.

[4] da Silva, V.d.P.R. (2004) On climate variability in Northeast of Brazil. Journal of Arid Environments, 58 (4), 575-596.

[5] Xu, J., Haginoya, S., Saito, K., Motoya, K. (2005) Surface heat balance and pan evaporation trends in Eastern Asia in the period 1971-2000. Hydrological Processes, 19 (11), 2161-2186.

[6] Oguntunde, P.G., Friesen, J., Nick, v.d.G., Savenije, H.H.G. (2006) Hydroclimatology of the Volta River Basin in West Africa: Trends and variability from 1901 to 2002. Physics and Chemistry of the Earth, Parts A/B/C, 31 (18), 1180-1188.

[7] Tabari, H., Marofi, S. (2011) Changes of Pan Evaporation in the West of Iran. Water Resources Management, 25 (1), 97-111.

[8] Peterson, T.C., Golubev, V.S., Groisman, P.Y. (1995) Evaporation losing its strength. Nature, 377, 687-688. 
[9] Golubev, V.S., Lawrimore, J.H., Groisman, P.Y., Speranskaya, N.A., Zhuravin, S.A., Menne, M.J., Peterson, T.C., Malone, R.W. (2001) Evaporation changes over the contiguous United States and the former USSR: A reassessment. Geophysical Research Letters, 28 (13), 2665-2668.

[10] Moonen, A.C., Ercoli, L., Mariotti, M., Masoni, A. (2002) Climate change in Italy indicated by agrometeorological indices over 122 years. Agricultural and Forest Meteorology, 111 (1), 13 27.

[11] Roderick, M.L., Farquhar, G.D. (2004) Change in Australian pan evaporation from 1970 to 2002. International Journal of Climatology, 24 (9), 1077-1099.

[12] Asanuma, J., Kamimera, H., Lu, M. (2004) Pan Evaporation Trends in Japan and its Relevance to the Variability of the Hydrological Cycle. Tenki, 51 (9), 667-678.

[13] Liu, B., Xu, M., Henderson, M., Gong, W. (2004) A spatial analysis of pan evaporation trends in China, 1955-2000. Journal of Geophysical Research, 109 (D15102), 1-9.

[14] Han, S., Xu, D., Wang, S. (2012) Decreasing potential evaporation trends in China from 1956 to 2005: Accelerated in regions with significant agricultural influence? Agricultural and Forest Meteorology, 154-155, 44-56.

[15] Tebakari, T., Yoshitani, J., Suvanpimol, C. (2005) Time-Space Trend Analysis in Pan Evaporation over Kingdom of Thailand. Journal of Hydrologic Engineering, 10 (3), 205-215.

[16] Limjirakan, S., Limsakul, A. (2012) Observed Trends in Surface Air Temperatures and Their Extremes in Thailand from 1970 to 2009. Journal of the Meteorological Society of Japan, 90 (5), 647-662.

[17] Jaswal, A.K., Prakasa Rao, G.S., De, U.S. (2008) Spatial and temporal characteristics of evaporation trends over India 1971-2000. MAUSAM, 59 (2), 149-158.

[18] Türkeş, M., Sümer, U., Kılıç, G. (1996) Observed Changes in Maximum and Minimum Temperatures in Turkey. International Journal of Climatology, 16 (4), 463-477.

[19] Türkeş, M., Sümer, U. (2007) Spatial and temporal patterns of trends and variability in diurnal temperature ranges of Turkey. Theoretical and Applied Climatology, 77 (3-4), 195-227.

[20] Türkeş, M., Koç, T., Sariş, F. (2008) Spatiotemporal variability of precipitation total series over Turkey. International Journal of Climatology, 29 (8), 1056-1074.

[21] Türkeş, M. (1996) Spatial and Temporal Analysis of Annual Rainfall Variations in Turkey. International Journal of Climatology, 16 (9), 1057-1076.

[22] Şensoy, S., Demircan, M., Alan, İ. (2005) 1971 - 2004 Y1lları Arası Türkiye İklim İndisleri Trendleri. Devlet Meteoroloji İşleri Genel Müdürlüğü, Ankara, Turkey.

[23] Aslantaş Bostan, P., Akyürek, Z. (2010) Spatio-Temporal Analysis of Precipitation and Temperature Distribution over Turkey. In: International Conference on Theory, Data Handling and Modelling in GeoSpatial Information Science. Hong Kong, Hong Kong: The International Archives of the Photogrammetry, Remote Sensing and Spatial Information Sciences.

[24] Aslantaş Bostan, P., Akyürek, Z. (2007) Türkiye'nin yıllık ve mevsimsel ortalama yağış ve sıcaklık değerlerinin trend analizi. In: V. Ulusal Hidroloji Kongresi. Ankara, Turkey: V. Ulusal Hidroloji Kongresi Bildirileri Kitabı.

[25] Aslantaş Bostan, P., Akyürek, Z. (2007) Exploring the mean annual precipitation and temperature values over Turkey by using environmental variables. In: ISPRS Joint Workshop "Visualization 
and Exploration of Geospatial Data". Stuttgart, Germany: International Society for Photogrammetry and Remote Sensing.

[26] Oğuz, İ., Öztekin, T., Akar, Ö. (2008) Examination of Long Period Precipitation and Temperature Trendlines at Tokat Kazova from Drought Point of View. Journal of Agricultural Faculty of Gaziosmanpasa University, 25 (1), 71-79.

[27] Karabulut, M. (2012) Analayses of Extreme Maximum and Mininum Heats at the East Mediterranian. KSU Journal of Natural Sciences, Special Issue, 37-44.

[28] Kızılelma, Y., Çelik, M.A., Karabulut, M. (2015) Trend analyses of temperature and precipitations in Central Anatolia. Türk Coğrafya Dergisi, 64, 1-10.

[29] Demir, İ., Kılıç, G., Coşkun, M., Sümer, U.M. (2008) Türkiye'de Maksimum, Minimum ve Ortalama Hava Sıcaklıkları ile Yağış Dizilerinde Gözlenen Değişiklikler ve Eğilimler. In: TMMOB İklim Değişimi Sempozyumu. Ankara, Turkey: TMMOB Meteoroloji Mühendisleri Odas1.

[30] Doğan Demir, A., Demir, Y. (2016) Mean, Minimum and Maximum Temperature Trends in Bingöl. Middle East Journal of Science, 2 (2), 101-109.

[31] Doğan Demir, A., Demir, Y., Şahin, Ü., Meral, R. (2017) Trend Analyses of Temperature and Precipitation and Effect on Agricultural in Bingol Province. Türk Tarım ve Doğa Bilimleri Dergisi, 4 (3), 284-291.

[32] Duman, E., Kara, F. (2017) A Study on Trends and Variability in Monthly Temperatures in Antalya Province between the Years 1960 and 2015. Journal of Scientific Research \& Reports, 14 (2), $1-16$.

[33] Yavuz, H., Erdoğan, S. (2012) Spatial Analysis of Monthly and Annual Precipitation Trends in Turkey. Water Resources Management, 26 (3), 609-621.

[34] Ozdogan, M., Salvucci, G.D. (2004) Irrigation-induced changes in potential evapotranspiration in southeastern Turkey: Test and application of Bouchet's complementary hypothesis. Water Resources Research, 40 (W04301), 1-12.

[35] Yeşilırmak, E. (2013) Temporal changes of warm-season pan evaporation in a semi-arid basin in Western Turkey. Stochastic Environmental Research and Risk Assessment, 27 (2), 311-321.

[36] Durdu, Ö.F. (2010) Effects of climate change on water resources of the Büyük Menderes river basin, western Turkey. Turkish Journal of Agriculture \& Forestry, 34 (4), 319-332.

[37] Sütgibi, S. (2015) Büyük Menderes Havzasının Sıcaklık, Yağış ve Akım Değerlerindeki Değişimler ve Eğilimler. Marmara Coğrafya Dergisi, 31, 398-414.

[38] Kale, S., Ejder, T., Hisar, O., Mutlu, F. (2016) Climate change impacts on streamflow of Karamenderes River (Çanakkale, Turkey). Marine Science and Technology Bulletin, 5 (2), 1-6.

[39] Kale, S., Ejder, T., Hisar, O., Mutlu, F. (2016) Effect of climate change on annual streamflow of Bakırçay River. Adıyaman University Journal of Science, 6 (2), 156-176.

[40] Ejder, T., Kale, S., Acar, S., Hisar, O., Mutlu, F. (2016) Restricted effects of climate change on annual streamflow of Sarıçay stream (Çanakkale, Turkey). Marine Science and Technology Bulletin, 5 (1), 7-11. 
[41] Ejder, T., Kale, S., Acar, S., Hisar, O., Mutlu, F. (2016) Effects of climate change on annual streamflow of Kocabaş stream (Çanakkale, Turkey). Journal of Scientific Research \& Reports, $11(4), 1-11$.

[42] Cengiz, T., Akbulak, C. (2009) Application of analytical hierarchy process and geographic information systems in land-use suitability evaluation: a case study of Dümrek village (Çanakkale, Turkey). International Journal of Sustainable Development \& World Ecology, 16 (4), 286-294.

[43] Pettitt, A.N. (1979) A Non-Parametric Approach to the Change-Point Problem. Journal of the Royal Statistical Society. Series C (Applied Statistics), 28 (2), 126-135.

[44] R Core Team, $R:$ A Language and Environment for Statistical Computing. $R$ Foundation for Statistical Computing, Vienna, Austria [online] https://www.R-project.org/version (07/2017). 2017.

[45] Pohlert, T. (2017) Trend: Non-Parametric Trend Tests and Change-Point Detection, R package version 0.1.0 [online] https://CRAN.R-project.org/package=trend.

[46] Hamed, K.H., Ramachandra Rao, A. (1998) A modified Mann-Kendall trend test for autocorrelated data. Journal of Hydrology, 204 (1-4), 182-196.

[47] Box, G.E.P., Jenkins, G. (1976) Time Series Analysis: Forecasting and Control. San Francisco: Holden Day.

[48] Kendall, M.G. (1955) Rank Correlation Methods. 2nd ed., New York: Hafner Publishing Co.

[49] Mann, H.B. (1945) Nonparametric Tests Against Trend. Econometrica, 13 (3), 245-259.

[50] Aydın, H., Düzen, H. (2011) Comparison of Measured and Calculated Evaporation Values of Open water surface-Lake Van (Turkey). In: 5. Atmospheric Science Symposium. İstanbul, Turkey: Devlet Meteoroloji İşleri Genel Müdürlügüü.

[51] Burn, D.H., Hesch, N.M. (2006) A Comparison of Trends in Potential and Pan Evaporation for the Canadian Prairies. Canadian Water Resources Journal, 31 (3), 173-184.

[52] Chattopadhyay, N., Hulme, M. (1997) Evaporation and potential evapotranspiration in India under conditions of recent and future climate change. Agricultural and Forest Meteorology, 87 (1), $55-73$.

[53] Roderick, M.L., Farquhar, G.D. (2005) Changes in New Zealand pan evaporation since the 1970s. International Journal of Climatology, 25 (15), 2031-2039.

[54] Breña-Naranjo, J.A., Laverde-Barajas, M.Á., Pedrozo-Acuña, A. (2017) Changes in pan evaporation in Mexico from 1961 to 2010. International Journal of Climatology, 37 (1), 204213.

[55] Alcamo, J., Moreno, J.M., Nováky, B., Bindi, M., Corobov, R., Devoy, R.J.N., Giannakopoulos, C., Martin, E., Olesen, J.E., Shvidenko, A. (2007) Europe, In: Climate Change 2007: Impacts, Adaptation and Vulnerability. Contribution of Working Group II to the Fourth Assessment Report of the Intergovernmental Panel on Climate Change, (Parry, M.L., Canziani, O.F., Palutikof, J., van der Linden, P., Hanson, C., Editors: Cambridge University Press, Cambridge, UK and New York, USA. p. 541-580.

[56] Zhang, X., Aguilar, E., Sensoy, S., Melkonyan, H., Tagiyeva, U., Ahmed, N., Kutaladze, N., Rahimzadeh, F., Taghipour, A., Hantosh, T.H., Albert, P., Semawi, M., Ali, M.K., Said AlShabibi, M.H., Al-Oulan, Z., Zatari, T., Al Dean Khelet, I., Hamoud, S., Sagir, R., Demircan, 
M., Eken, M., Adiguzel, M., Alexander, L., Peterson, T.C., Wallis, T. (2005) Trends in Middle East climate extreme indices from 1950 to 2003. Journal of Geophysical Research: Atmospheres, 110 (D22104), 1-12.

[57] Abtew, W., Obeysekera, J., Iricanin, N. (2011) Pan Evaporation and Potential Evapotranspiration Trends in South Florida. Hydrological Processes, 25 (6), 958-969.

[58] McVicar, T.R., Roderick, M.L. (2010) Atmospheric science: Winds of change. Nature Geoscience, 3 (11), 747-748.

[59] Vautard, R., Cattiaux, J., Yiou, P., Thépaut, J.-N., Ciais, P. (2010) Northern Hemisphere atmospheric stilling partly attributed to an increase in surface roughness. Nature Geoscience, 3 (756-761).

[60] McVicar, T.R., Roderick, M.L., Donohue, R.J., Li, L.T., Van Niel, T.G., Thomas, A., Grieser, J., Jhajharia, D., Himri, Y., Mahowald, N.M., Mescherskaya, A.V., Kruger, A.C., Rehman, S., Dinpashoh, Y. (2012) Global review and synthesis of trends in observed terrestrial near-surface wind speeds: Implications for evaporation. Journal of Hydrology, 416-417, 182-205.

[61] Ji, F., Wu, Z., Huang, J., Chassignet, E.P. (2014) Evolution of land surface air temperature trend. Nature Climate Change, 4, 462-466.

[62] Chen, Y., Xu, Z. (2005) Plausible impact of global climate change on water resources in the Tarim River Basin. Science in China Series D: Earth Sciences, 48 (1), 65-73. 